\title{
A deeper look at the relationship between root carbon pools and the vertical distribution of the soil carbon pool
}

\author{
Ranae Dietzel, Matt Liebman, and Sotirios Archontoulis \\ Department of Agronomy, Iowa State University, Ames, IA 50011, USA \\ Correspondence to: Ranae Dietzel (ranae.dietzel@gmail.com)
}

Received: 25 January 2017 - Discussion started: 27 February 2017

Revised: 15 June 2017 - Accepted: 11 July 2017 - Published: 22 August 2017

\begin{abstract}
Plant root material makes a substantial contribution to the soil organic carbon (C) pool, but this contribution is disproportionate below $20 \mathrm{~cm}$ where $30 \%$ of root mass and $50 \%$ of soil organic C is found. Root carbon inputs changed drastically when native perennial plant systems were shifted to cultivated annual plant systems. We used the reconstruction of a native prairie and a continuous maize field to examine both the relationship between root carbon and soil carbon and the fundamental rooting system differences between the vegetation under which the soils developed versus the vegetation under which the soils continue to change. In all treatments we found that root $\mathrm{C}: \mathrm{N}$ ratios increased with depth, and this plays a role in why an unexpectedly large proportion of soil organic $\mathrm{C}$ is found below $20 \mathrm{~cm}$. Measured root $\mathrm{C}: \mathrm{N}$ ratios and turnover times along with modeled root turnover dynamics showed that in the historical shift from prairie to maize, a large, structural-tissue-dominated root $\mathrm{C}$ pool with slow turnover concentrated at shallow depths was replaced by a small, nonstructural-tissue-dominated root $\mathrm{C}$ pool with fast turnover evenly distributed in the soil profile. These differences in rooting systems suggest that while prairie roots contribute more $\mathrm{C}$ to the soil than maize at shallow depths, maize may contribute more $\mathrm{C}$ to soil $\mathrm{C}$ stocks than prairies at deeper depths.
\end{abstract}

\section{Introduction}

Prairie-formed Mollisols support some of the world's most productive agriculture, but declines in levels of soil organic matter threaten the reliability of this production. Soil organic matter losses coincide with a shift from perennial plant systems to annual cropping systems that introduced frequent tillage, subsurface drainage, and differences in organic matter inputs, including considerably different rooting systems (Davidson and Ackerman, 1993; Huggins et al., 1998; Guo and Gifford, 2002). The effects of changes in soil management, such as increased soil disturbance and aeration, the addition of fertilizers, and changes in residue amount and quality, have often been cited as primary factors in the changes of soil organic matter from native levels (Buyanovsky et al., 1987; Huggins et al., 1998; David et al., 2009; Gregory et al., 2016). The role played by changes in rooting systems, on the other hand, is difficult to study and has received less attention.

In this paper, we distinguish between a root $\mathrm{C}$ pool defined as $\mathrm{C}$ found in any material that can still be visually identified as a root and a soil organic $\mathrm{C}$ pool defined as the rest of the soil organic C. Root growth allows for the placement of plant tissue directly into the soil, creating a root $\mathrm{C}$ pool as deep as the rooting system occupies. Some studies suggest that root $\mathrm{C}$ pool size and soil organic $\mathrm{C}$ pool size have a direct relationship and that most soil organic matter is derived from roots (Balesdent and Balabane, 1996; Rasse et al., 2005; Kong and Six, 2010). This would mean that a change in root inputs, such as that engendered by switching from annual to perennial systems, would have a direct impact on soil organic matter even deep into the soil profile. However, few direct comparisons of annual and perennial rooting systems have been made, and our understanding of soil $\mathrm{C}$ dynamics decreases as soil depth increases. 
On average, half of the world's soil C is found below $20 \mathrm{~cm}$ (Rumpel and Kögel-Knabner, 2011). However, only $30 \%$ of the world's roots are found below $20 \mathrm{~cm}$ (Jobbágy and Jackson, 2000). In the central US, this phenomenon was observed as early as 1935 when Weaver et al. (1935) found 41-74\% of the total soil organic matter, but only 23-29\% of the total root mass in a tallgrass prairie was below $20 \mathrm{~cm}$. Similarly, Gill et al. (1999) found $77 \%$ of total soil organic matter but only $43 \%$ of total root mass below $15 \mathrm{~cm}$ in a shortgrass steppe. Although this disproportionate relationship between root and soil $\mathrm{C}$ distribution has been known for some time, no widely accepted explanation exists to explain the magnitude of difference between the amount of $\mathrm{C}$ in the root pool and the amount of $\mathrm{C}$ in the soil pool (Gill et al., 1999; Rumpel and Kögel-Knabner, 2011).

Many factors interact to determine how much $\mathrm{C}$ is transferred between pools and how much $\mathrm{C}$ remains in a particular pool. Soil temperature, moisture, $\mathrm{O}_{2}$ availability (Gill and Burke, 2002), and energy availability (Fontaine et al., 2007) are important environmental variables controlling the rate of decomposition and soil texture, and existing soil $\mathrm{C}$ levels determine the length of time $\mathrm{C}$ remains in the soil (Six et al., 2002; Rasse et al., 2005). The $\mathrm{C}: \mathrm{N}$ ratio of the organic matter being decomposed also plays a key role in both the rate of decomposition and the fate of the decomposed organic matter, with higher $\mathrm{C}: \mathrm{N}$ ratios leading to slower decomposition (Silver and Miya, 2001) and fewer microbial by-products (Cotrufo et al., 2015). Temperature, moisture, $\mathrm{O}_{2}$, soil texture, and soil $\mathrm{C}$ levels all vary with soil depth and contribute to partial explanations for the size discrepancy between root and soil $\mathrm{C}$ pools. However, previous studies that measured roots and/or organic matter with depth have neglected to report the change in the root $\mathrm{C}: \mathrm{N}$ ratio with depth (Tufekcioglu et al., 2003; Beniston et al., 2014). C: $\mathrm{N}$ ratio differences between maize and prairie root $\mathrm{C}$ pools are also unknown. A more detailed look at the properties of root $\mathrm{C}$ pools is needed.

We studied the belowground reconstruction of native vegetation on a Mollisol over 6 years and after $>100$ years of annual cropping to gain a new perspective on characteristics of root inputs that would not necessarily be detected in established prairie systems where many processes are at slow, steady states. We examined differences between maize and reconstructed prairie root pools to a depth of $1 \mathrm{~m}$ to serve two separate but related purposes: (1) to inform our understanding of the impacts of shifting millions of hectares from perennial to annual vegetation and (2) contribute to an explanation of why levels of soil organic $C$ found below $20 \mathrm{~cm}$ are greater than expected based on root distribution. In comparing the root $\mathrm{C}$ pool of a reconstructed prairie system to the root $\mathrm{C}$ pool of a maize cropping system, we asked the following questions: (1) how does the quantity, distribution, and $\mathrm{C}: \mathrm{N}$ ratio of the root $\mathrm{C}$ pool differ with depth and between these native perennial and non-native annual ecosystems? (2) What do these differences in inputs tell us about the differing effects of the perennial prairie ecosystem under which these soils developed and the annual cropping systems under which these soils continue to change?

\section{Materials and methods}

\subsection{Site conditions and experimental design}

We conducted the experiment in Boone County, IA, USA on the Iowa State University Agronomy and Agricultural Engineering Research Farm $\left(41^{\circ} 55^{\prime} \mathrm{N}, 93^{\circ} 45^{\prime} \mathrm{W}\right)$. Soils at the site were primarily Webster silty clay loam (fine-loamy, mixed, superactive, mesic Typic Endoaquolls) and Nicollet loam (fine-loamy, mixed, superactive, mesic Aquic Hapludolls). The 60-year mean growing season precipitation $11 \mathrm{~km}$ from the site was $720 \mathrm{~mm}$. Prior to initiation of the field experiment in 2008, the site was used for maize and soybean production and was planted with soybean in 2007. Soil sampling to $15 \mathrm{~cm}$ in November 2007 indicated that the mean soil pH was 6.7 , the mean soil $\mathrm{C}$ concentration (via dry combustion analysis) was $30 \mathrm{~g} \mathrm{~kg}^{-1}$, the mean extractable phosphorus concentration (via Bray 1 procedure) was $11 \mathrm{mg} \mathrm{kg}^{-1}$, and the mean extractable potassium (via Mehlich 3 procedure) was $141 \mathrm{mg} \mathrm{kg}^{-1}$.

Experimental plots were $27 \times 61 \mathrm{~m}$ areas replicated four times and arranged as a spatially balanced complete block design (van Es et al., 2007). The three cropping systems used for the present study were continuous maize with annual removal of grain and about $50 \%$ of the stover (hereafter maize), reconstructed multispecies prairie with annual aboveground biomass removal (hereafter unfertilized prairie), and $\mathrm{N}$-fertilized reconstructed multispecies prairie with annual aboveground biomass removal (hereafter fertilized prairie). All of the treatments were managed without tillage. Conventional farm machinery was used for planting, fertilization, crop protection, and harvest operations. Herbicides were not used in the prairie systems except for a small number of spot treatments for Canada thistle (Cirsium canadensis) control, and the timing and frequency of herbicide use in the annual cropping systems varied among treatments.

Both prairie treatments were sown on 19 May 2008 with the same custom seed mix obtained from Prairie Moon Nursery (Winona, MN, USA) that contained 31 species, including $\mathrm{C} 3$ and $\mathrm{C} 4$ grasses and leguminous and non-leguminous forbs. All species were perennial and sourced from within $240 \mathrm{~km}$ of the experiment site. The composition of the seed mix by weight was $12 \% \mathrm{C} 3$ grasses, $56 \% \mathrm{C} 4$ grasses, $8 \%$ legumes, and $24 \%$ non-leguminous forbs. A detailed description of the prairie plant community compositions can be found in Jarchow and Liebman (2013). The fertilized prairie treatment received no fertilizer in 2008 (the establishment year) but was fertilized at a rate of $84 \mathrm{~kg} \mathrm{Nha}^{-1}$ year $^{-1}$ in all subsequent years. This fertilizer rate was chosen because it was similar to the maximum rate of pre-planting $\mathrm{N}$ fertiliza- 
tion recommended for maize (Blackmer et al., 1997) and the expected $\mathrm{N}$ removal in the harvested biomass of perennial grasses grown in the area (Heggenstaller et al., 2009).

The maize used was a 104-day relative maturity hybrid (Agrigold 6325 VT3) with transgenes for glyphosate resistance, corn borer (Ostrinia nubilalis) resistance, and corn rootworm (Diabrotica spp.) protection. Maize was planted following standard practices in rows spaced $76 \mathrm{~cm}$ apart at a seeding rate between 79500 and 82500 seeds ha $^{-1}$, depending on the year. Fertilizer rates for corn were based on soil testing results (Blackmer et al., 1997) and varied from 123 to $200 \mathrm{~kg} \mathrm{Nha}^{-1}$, depending on the year.

\subsection{Data collection}

\subsubsection{Soil collection}

Soil cores were taken to $1 \mathrm{~m}$ of depth in all plots each year using a hydraulic soil probe (Giddings Machine Co., Windsor, CO, USA) after all crop and prairie plots were harvested. Sampling occurred by replicate block from 31 October to 25 November 2008, 9-11 November 2009, 25-28 October 2010, 28-31 October 2011, 16-17 October 2012, and 711 November 2013.

In 2008, two cores were taken per plot. A $0-30 \mathrm{~cm}$ fraction was taken with a $10.2 \mathrm{~cm}$ internal diameter soil probe; the $30-100 \mathrm{~cm}$ fractions of the cores were taken within the same hole as the $0-30 \mathrm{~cm}$ fraction, but with a smaller soil probe. In Blocks 1 and 4, the internal diameter of the core was $6.0 \mathrm{~cm}$. In Blocks 2 and 3, the internal diameter of the core was $5.2 \mathrm{~cm}$. In 2009 and 2010 , four cores were taken per plot. The $0-30 \mathrm{~cm}$ fraction of the cores was taken with a $10.2 \mathrm{~cm}$ internal diameter soil probe; the $30-100 \mathrm{~cm}$ fractions of the cores were taken directly below the $0-30 \mathrm{~cm}$ fraction with a $5.1 \mathrm{~cm}$ internal diameter probe. For 2011-2013, four cores were taken per plot, and the entire core was taken with a $5.1 \mathrm{~cm}$ internal diameter probe.

Soil cores were ultimately divided into three or five depth increments. In 2008, depth increments were 0-30, 30-60, and $60-100 \mathrm{~cm}$. For $2009-2013$ depth increments were 0$5,5-15,15-30,30-60$, and $60-100 \mathrm{~cm}$. Following division and extraction from the field, soil cores were stored at $5{ }^{\circ} \mathrm{C}$ until processing was initiated.

Each year, 60-100 g of root-free soil was removed from each depth increment, air-dried, and archived in airtight containers at room temperature. In 2008 and 2013, this soil was ground on a roller mill and organic $\mathrm{C}$ content was determined by catalytic oxidation and $\mathrm{CO}_{2}$ measurement measurement with a nondispersive infrared (NDIR) sensor in an Elementar TOC Cube at Brookside Laboratories, Inc. (New Bremen, OH, USA).

\subsubsection{Root pool collection}

Two sets of root pool measurements were collected: (a) endof-season root measurements for each year (depth 0-100 cm) and (b) in-season root measurements during 2010 and 2011 (depth $0-30 \mathrm{~cm}$ ). The first, described in this section, was used to track changes in the root $\mathrm{C}$ pools over all 6 years, and the second, described in Sect. 2.2.3, was used to quantify annual root $\mathrm{C}$ contributions in 2010 and 2011.

Root extraction from the soil began by washing the soil samples described in Sect. 2.2.1 in wire mesh tubes $(0.28 \mathrm{~mm}$ mesh) for $3 \mathrm{~h}$ in an elutriator (Wiles et al., 1996). Roots were removed from the remaining soil by suspending the airdried sample in water and collecting the roots, which floated, with sieves followed by manual removal of any remaining non-root material that was present in the samples. Any plant crowns that were present in the samples were removed and were not considered to be root biomass. Roots were then dried at $70^{\circ} \mathrm{C}$ for at least $4 \mathrm{~h}$ before being weighed. All root samples were ground to $2 \mathrm{~mm}$ with a centrifugal mill and concentrations of $\mathrm{C}$ and $\mathrm{N}$ were determined by combustion analysis at the Soil and Plant Analysis Laboratory at Iowa State University (Ames, IA, USA).

\subsubsection{In-season root growth}

In 2010 and 2011, root biomass was measured with an in situ growth core approach (Neill, 1992) to capture only those roots growing within the measurement year. After fall harvest in 2009 and 2010 , eight $10.2 \mathrm{~cm}$ diameter soil cores were taken to $30 \mathrm{~cm}$ of depth in each plot and brought to the laboratory. Holes created in the field were held open during the winter by capped $10.2 \mathrm{~cm}$ PVC piping. In the laboratory, cores were divided into $10 \mathrm{~cm}$ sections and virtually all roots were removed by hand. Soil was stored in intact cores at $30^{\circ} \mathrm{C}$ for the first year of the experiment (intended to be used for an incubation experiment) and $4{ }^{\circ} \mathrm{C}$ in sealed plastic bags for the second year of the experiment. The differences in storage conditions did not have an apparent effect on the outcome of the experiment. At the end of winter while plants were still dormant, the root-free soil was returned to its original location in the field in $10 \mathrm{~cm}$ depth increments. Soil was packed to imitate the surrounding bulk density, approximately $1.4 \mathrm{~g} \mathrm{~cm}^{-3}$. Root-free zones were located randomly within prairie plots and at $20 \mathrm{~cm}$ from maize rows. Eight root-free areas were situated within each plot, allowing for duplicate sampling at four time points throughout the growing season. Two $4 \mathrm{~cm}$ diameter soil cores were taken within each $10.2 \mathrm{~cm}$ diameter root-free area to a $30 \mathrm{~cm}$ depth at each root sampling date. Bulk soil was washed from the roots with water using a soil elutriator (Wiles et al., 1996), roots were dried at $60^{\circ} \mathrm{C}$ for $24 \mathrm{~h}$, non-root biomass was removed from the roots by hand, and roots were weighed.

\subsection{Data analysis}

The root pool mass for the entire meter depth was calculated by summing the root mass for each depth increment of an entire core, and whole core root masses were com- 
pared between treatments within each year using contrasts within a linear mixed-effects model in the R package nlme (Pinheiro et al., 2013). Treatment differences within depths within years and differences between treatments within depths within years for root biomass were also made with contrasts with linear mixed-effects models using proc glimmix in SAS (SAS Institute, 2011). Block $\times$ treatment and block $\times$ trt $\times$ core interactions were treated as random effects.

Because root mass in 2008 was measured at three increments $(0-30,30-60$, and $60-100 \mathrm{~cm})$ instead of the five increments used later in the experiment $(0-5,5-15,15-30$, $30-60$, and $60-100 \mathrm{~cm}$ ), 2008 root mass for $0-5,5-15$, and $15-30 \mathrm{~cm}$ depths was estimated by multiplying the average 2009-2013 depth distribution proportions by the 20080 $30 \mathrm{~cm}$ increment. No important comparisons were made using these estimated data, but the data were used as a starting point for graphing $\mathrm{C}: \mathrm{N}$ ratios in different depth increments and fitting curves to root accumulation. $\mathrm{C}: \mathrm{N}$ ratios were compared between treatments within years within depths and between years within treatments within depths using proc glimmix in SAS.

Root mass measured at the end of each growing season was subset by depth increment, and each subset was fit by both a logistic model and a linear model for each plot. Logistic models and linear models were compared against each other using Akaike's information criterion (AIC) and the model with the lowest AIC was chosen. The AIC was not greatly different for any of the comparisons, but the logistic model had the best fit for every depth. Model fits and comparisons were done using the $\mathrm{R}$ package nlme (Pinheiro et al., 2013), and the methods are explained in more detail by Pinheiro and Bates (2000).

The first derivative of the logistic model was used to calculate the daily rate of root mass accumulation or the net gain in root mass each day. Parameters from the logistic model were used to predict both the amount and rate of accumulation for each day for each depth in each plot of the experiment. These predictions were averaged for each treatment and plotted. The annual mean rate was calculated by averaging accumulation rates across each growing season for each depth in each plot. Comparisons of rates between treatments within depths and within years and comparisons of rates between depths within treatments within years were made with proc glimmix in SAS.

The models used to fit root mass over time did not accurately reflect within-year biomass fluctuations caused by the start and stop of plant growth and freezing and thawing of soil; rather, these curves were used to compare long-term trends in root mass accumulation. Accordingly, the daily rate of root mass accumulation was also inaccurate, but it was very useful to compare relative accumulation rates among treatments and soil depths. An average daily root mass accumulation rate was calculated by considering the period of possible root growth and decomposition to be between
Table 1. Soil characteristics measured at the establishment of the experiment.

\begin{tabular}{lrrrrrrr}
\hline Depth & $\begin{array}{r}\text { Bulk } \\
\text { density }\end{array}$ & $\mathrm{pH}$ & Total C & Total N & Sand & Silt & Clay \\
\cline { 4 - 8 }$(\mathrm{cm})$ & $\left(\mathrm{g} \mathrm{cm}^{-3}\right)$ & & \multicolumn{6}{c}{$(\%)$} \\
\hline $0-5$ & 1.28 & 6.36 & 2.81 & 0.24 & 37.5 & 36.8 & 25.8 \\
$5-15$ & 1.41 & 5.85 & 2.55 & 0.22 & 37.5 & 36.0 & 26.6 \\
$15-30$ & 1.50 & 5.94 & 2.14 & 0.18 & 35.4 & 35.8 & 28.9 \\
$30-60$ & 1.45 & NA & 1.23 & 0.11 & NA & NA & NA \\
$60-100$ & 1.60 & NA & 0.95 & 0.05 & NA & NA & NA \\
\hline
\end{tabular}

Table 2. Root pool and soil organic $\mathrm{C}$ found above and below $20 \mathrm{~cm}$.

\begin{tabular}{lrrrrrr}
\hline Treatment & Depth & Root C & Soil C & & Root C & Soil C \\
\cline { 3 - 4 } \cline { 6 - 7 } & $(\mathrm{cm})$ & \multicolumn{2}{c}{$\left(\mathrm{Mg} \mathrm{ha}^{-1}\right)$} & & \multicolumn{2}{c}{ (proportion) } \\
\hline \multirow{2}{*}{ Maize } & $0-20$ & 0.27 & 71.17 & & 0.38 & 0.44 \\
& $20-100$ & 0.43 & 89.97 & & 0.62 & 0.56 \\
\hline Unfertilized & $0-20$ & 3.16 & 79.14 & & 0.72 & 0.48 \\
prairie & $20-100$ & 1.26 & 85.00 & & 0.28 & 0.52 \\
\hline Fertilized & $0-20$ & 1.47 & 76.66 & & 0.63 & 0.50 \\
prairie & $20-100$ & 0.85 & 76.54 & & 0.37 & 0.50 \\
\hline
\end{tabular}

1 April and 30 November (the approximate growing season) in each year.

In situ root measurements in 2010 and 2011 combined with differences in root pool masses at $30 \mathrm{~cm}$ over these years were used to calculate a root turnover constant $(k)$ and root mean residence time (MRT) using the equations $k=$ input/pool and MRT $=1 / k$. Root input values were calculated from the in situ growth cores and functional growth analysis described by Dietzel and Liebman (2015). The root mass measured at the end of each year was the pool value.

The height and volume of root samples varied among depth increments, making visual comparisons among depths, such as $0-5$ and $60-100 \mathrm{~cm}$, difficult. Thus, splines were fit to the data and integrated by $5 \mathrm{~cm}$ depths to facilitate the visualization of root and soil organic $\mathrm{C}$ distribution in the soil profile.

\section{Results}

Our study site had soil characteristics typical for a Webster silty clay loam. Both total $\mathrm{C}$ and total $\mathrm{N}$ decreased with depth but maintained a relatively constant relationship (mean $\mathrm{C}: \mathrm{N}$ ratio $=11.6)$ until $60-100 \mathrm{~cm}$, where the $\mathrm{C}: \mathrm{N}$ ratio was 19 (Table 1).

The total amount of organic $\mathrm{C}$ found in the soil 6 years after the establishment of the experiment did not differ among treatments at any depth (Fig. 1), nor was it different from initial total organic $\mathrm{C}$ levels measured at the beginning of the experiment (data not shown). Half of the total soil organic 
Table 3. Root turnover at $0-30 \mathrm{~cm}$.

\begin{tabular}{|c|c|c|c|c|c|}
\hline \multirow[t]{2}{*}{ Year } & \multirow[t]{2}{*}{ Treatment } & Input & Pool & \multirow[t]{2}{*}{$k$} & \multirow{2}{*}{$\begin{array}{l}\text { MRT } \\
\text { (years) }\end{array}$} \\
\hline & & \multicolumn{2}{|c|}{$\left(\mathrm{Mgha}^{-1}\right)$} & & \\
\hline \multirow{3}{*}{2010} & Unfertilized prairie & 3.67 & 7.48 & 0.49 & 2.04 \\
\hline & Fertilized prairie & 1.46 & 2.31 & 0.63 & 1.58 \\
\hline & Maize & 0.56 & 0.44 & 1.27 & 0.79 \\
\hline \multirow{3}{*}{2011} & Unfertilized prairie & 3.87 & 7.58 & 0.51 & 1.96 \\
\hline & Fertilized prairie & 1.68 & 3.42 & 0.49 & 2.03 \\
\hline & Maize & 0.48 & 0.47 & 1.01 & 0.99 \\
\hline
\end{tabular}

$\mathrm{C}$ was found below $20 \mathrm{~cm}$ (Table 2). The pattern of vertical soil $\mathrm{C}$ distribution was similar to the pattern of maize root distribution, not prairie root distribution (Fig. 1).

Six years after the establishment of the experiment, the unfertilized prairie root $C$ pool was almost 6 times greater than the maize root $\mathrm{C}$ pool, and the fertilized prairie root $\mathrm{C}$ pool was 3.5 times greater than the maize root $\mathrm{C}$ pool over a $1 \mathrm{~m}$ depth. Overall, $28 \%$ of the unfertilized prairie root $\mathrm{C}$ pool, $37 \%$ of the fertilized prairie root $\mathrm{C}$ pool and $62 \%$ of the maize root $\mathrm{C}$ pool was found below $20 \mathrm{~cm}$ (Fig. 2, Table 2).

Prairie rooting systems were established sequentially in the soil profile from the top down as shown by differences in the timing of peak accumulation rates (Fig. 4). The top $5 \mathrm{~cm}$ of the root pool peaked in the first full year of growth and then reached an equilibrium during the second full year of growth with large year-to-year variability given the sensitivity of this thin surface layer to environmental conditions (Fig. A1-A3). The next soil layer, from 5 to $15 \mathrm{~cm}$, had the greatest increase in root pool mass during the second full year of prairie growth. In contrast, the $15-30$ and $30-60 \mathrm{~cm}$ depths did not reach peak rates of root pool accumulation until 5 and 6 years after establishment with no indication of when accumulation would cease. In the unfertilized prairie, the rates of root pool accumulation in $60-100 \mathrm{~cm}$ of soil in the sixth year were greater than all other depths with no sign of slowing down. Fertilized prairie also had a high rate of root pool accumulation at $60-100 \mathrm{~cm}$ in the sixth year with no sign of decreasing (Fig. 4).

Maize root pool accumulation was almost always slower than prairie root pool accumulation with the exception of the top $5 \mathrm{~cm}$ after 2010, 60-100 $\mathrm{cm}$ before 2011 (not different from fertilized prairie), and a greater value in maize than unfertilized prairie at $30-60 \mathrm{~cm}$ in 2013 . There was no difference in maize root pool accumulation among depths until 2011 when accumulation below $15 \mathrm{~cm}$ then began to exceed accumulation above $15 \mathrm{~cm}$ (Fig. 4).

Prairie roots had a mean residence time (MRT) of 1.90 years in the top $30 \mathrm{~cm}$ of the profile when averaged across treatments and years (2010 and 2011). Maize roots turned over almost twice as fast as prairie roots when averaged across treatments and years (Table 3 ).
$\mathrm{C}: \mathrm{N}$ ratios increased with depth in all treatments (Fig. 5). $\mathrm{C}: \mathrm{N}$ ratios increased in both prairie treatments in every depth over time, although the increase in fertilized prairie was not always different between consecutive years. In all treatments, changes in $\mathrm{C}: \mathrm{N}$ ratios were the result of both an increase in $\mathrm{C}$ content and a decrease in $\mathrm{N}$ content (data not shown). The maize root pool did not exhibit an increase in $\mathrm{C}: \mathrm{N}$ ratio over time (Fig. 5).

\section{Discussion}

\subsection{Reconstruction of a prairie root C pool and implications for $\mathrm{C}$ contribution}

An increase in root pool $\mathrm{C}: \mathrm{N}$ ratio with depth has not been previously reported in the literature or considered when trying to determine why a disproportionately large amount of soil $\mathrm{C}$ is found at depth when compared to root distribution. It has been recently theorized that plant tissue becomes organic matter through two different pathways: (1) a dissolved organic $\mathrm{C}$ microbial pathway whereby plant litter is first processed by soil microbes and eventually transported and stabilized in the soil matrix as a microbial by-product if the soil has the capacity to stabilize these compounds and (2) a physical transfer pathway whereby plant tissue is processed by soil microbes until it remains in the soil due to inherent chemical recalcitrance (Cotrufo et al., 2015). In the present study, the former pathway is more applicable to tissue dominated by nonstructural compounds, such as that with lower $\mathrm{C}: \mathrm{N}$ ratios found at shallower depths, whereas the latter pathway applies to tissue dominated by structural compounds indicated by high $\mathrm{C}: \mathrm{N}$ ratios in root tissue at greater depth. Under this framework, root decomposition in our study would have resulted in a gradient of microbially derived to physically derived organic matter from the top of the soil profile downward. In turn, this would mean that soil organic matter at the soil surface would be vulnerable to transport to greater depth as dissolved organic $\mathrm{C}$, whereas physically transferred soil organic matter at depth would be relatively immobile. This is a possible mechanism by which the amount of soil organic $\mathrm{C}$ found at depth is disproportionately large compared to the size of the root $C$ pool. This mechanism would be particularly strong in soils that are high in $\mathrm{C}$ and have a reduced capacity for $\mathrm{C}$ stabilization nearer to the surface, such as soils formed under prairie vegetation (Castellano et al., 2015). This suggested mechanism is also consistent with evidence that the contribution of microbial-derived and not root-derived C increases with depth (Liang and Balser, 2008; Rumpel and Kögel-Knabner, 2011). In addition to the lessstructural root material found at shallow depths, these areas of concentrated roots produce labile exudates that are easily metabolized and transported deeper in the soil profile (Badri and Vivanco, 2009), again under conditions that do not favor immediate stabilization of the metabolites. While we did not measure root exudates, it is important to recognize that these 


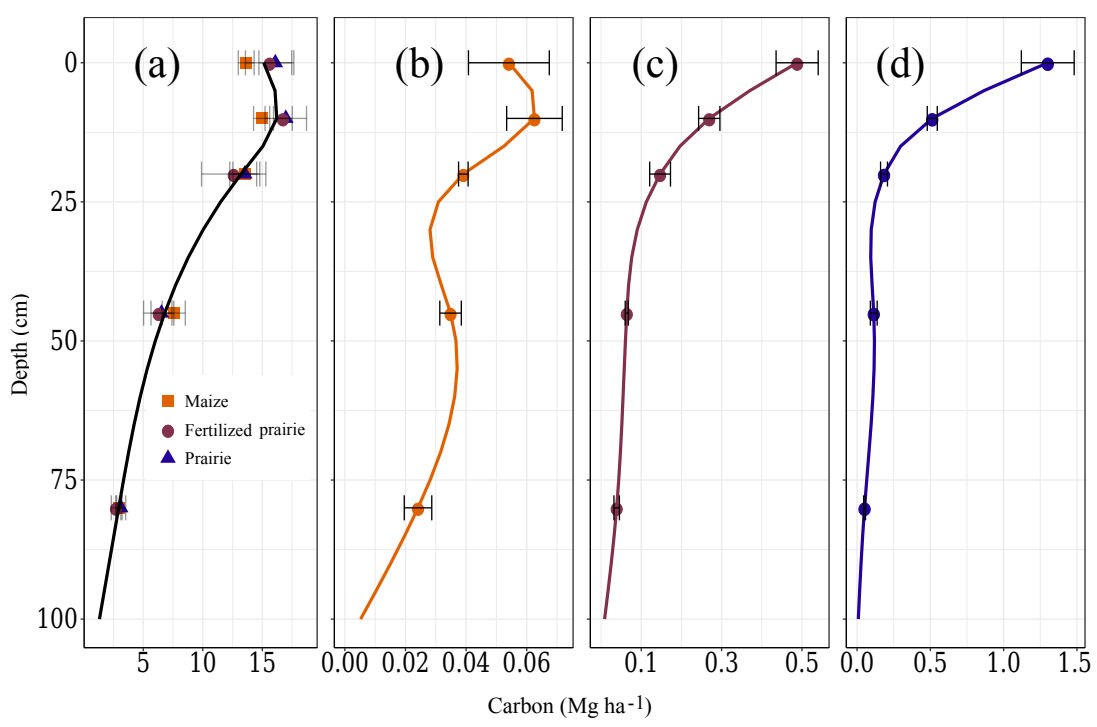

Figure 1. (a) Total soil carbon with each treatment represented by a point and the site average represented by a solid line for (b) maize root carbon, (c) fertilized prairie root carbon, (d) and unfertilized prairie root carbon measured in 2013, which is 6 years after the establishment of the experiment. Different $x$-axis scales are used to emphasize similarities and differences in profile distribution patterns, not absolute mass amounts (see Fig. 2).

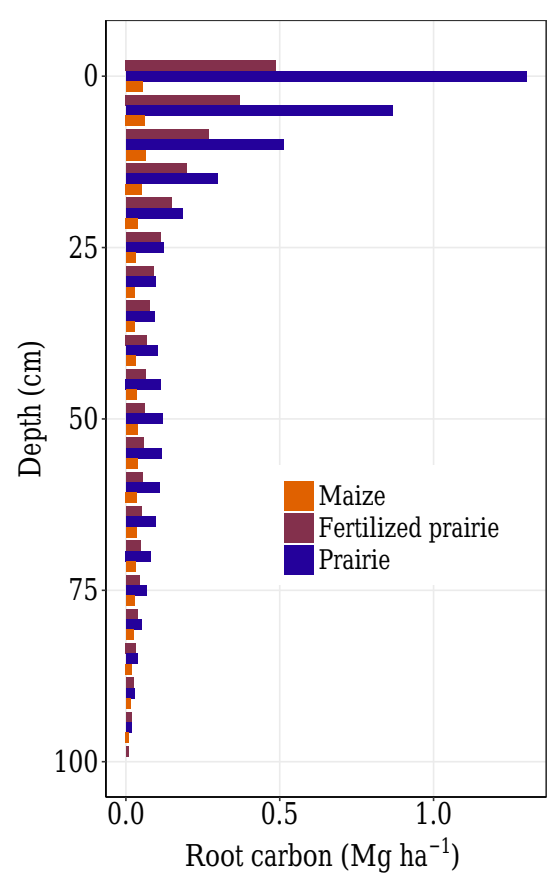

Figure 2. Absolute difference in root $\mathrm{C}$ pools 6 years after prairie establishment.

mobile compounds also likely play an important role in the development of the soil organic $\mathrm{C}$ profile.

Because the root pool is made up of a combination of new, mature, aging, and dead roots, an increase in its mass comes from root growth, live root retention, and inhibited root de- composition. The relatively quick rate of accumulation in the top $30 \mathrm{~cm}$ of soil was most likely a function of new root addition, which slowed as the system became more established (Fig. 4). Slower increases at deeper depths than shallower depths may indicate that accumulation there is more dependent upon the carryover of roots from previous years than at shallower depths, although annual root inputs were not directly measured in this study.

By the sixth year of reconstructed prairie establishment, root $C$ pool equilibrium was reached and prairies began making substantial annual inputs to the soil organic matter pool above $30 \mathrm{~cm}$ (Figs. 3 and 4), although the fraction of organic matter that remained in the soil is unknown. This was indicated by the finding that the majority of prairie roots $(75 \%)$ was found in this depth fraction where the mean residence time was measured to be $\sim 2$ years (Tables 2 and 3 ). The prairie root $C$ pool at $0-5 \mathrm{~cm}$ reached an equilibrium and began steady root turnover in the third year after establishment, as indicated by very low rates of accumulation, and was likely able to contribute material to the soil organic matter pool at this time. Other prairie restorations have also found soil organic matter accumulation to be most rapid closer to the soil surface (O'Brien et al., 2010; Omonode and Vyn, 2006).

Annual prairie root inputs were not measured below $30 \mathrm{~cm}$, so turnover rates could not be calculated. However, continuous increases in the root pool at depth (Fig. 3) due to root growth and retention indicate that root tissue loss to the soil was very low during this time and the mean residence time of roots at depth may have greatly exceeded those closer to the surface. This means that at depth, not only was the root 


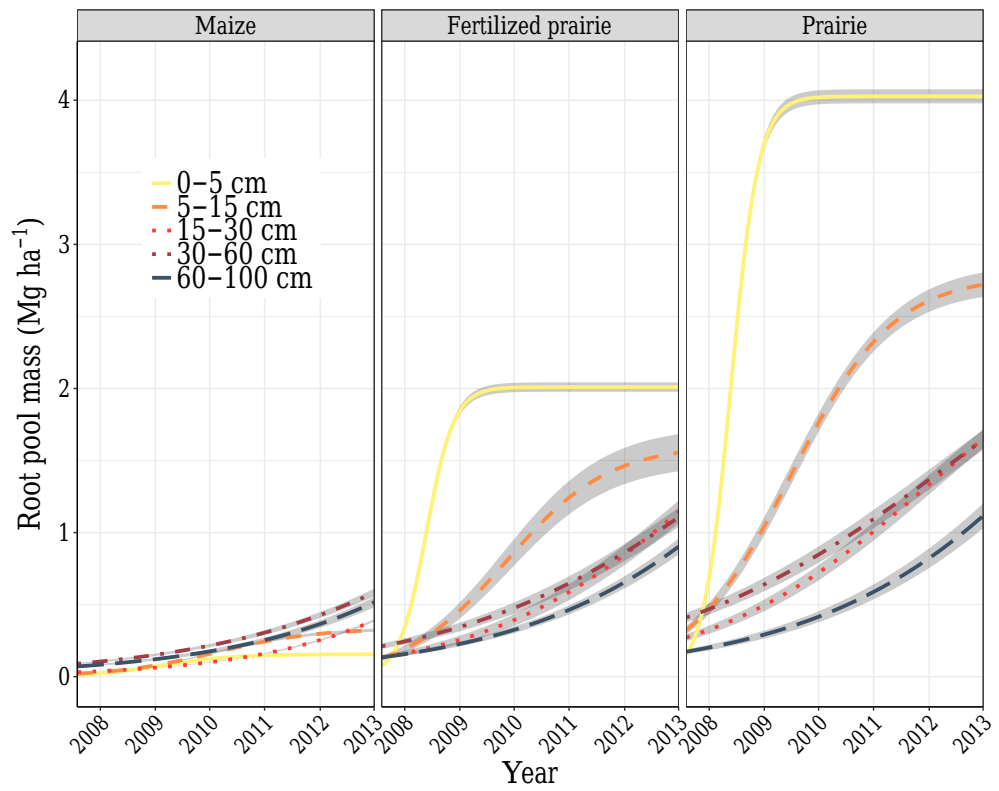

Figure 3. Modeled accumulation of root pool mass over 6 years at 0-5, 5-15, 15-30, 30-60, and 60-100 cm. Grey shading represents 1 standard error of the mean. Seasonal effects are smoothed.

C pool substantially smaller than near the surface, but root material also became available to the soil much more slowly than near the surface. Indeed, DuPont et al. (2014) found intact prairie roots in the soil 5 years after conversion to annual wheat.

The nitrogen fertilization of prairies led to a smaller root pool at every depth with lower rates of accumulation and lower $\mathrm{C}: \mathrm{N}$ ratios (Figs. 2, 4, 5). However, fertilization did not affect the time until root systems were fully established or the turnover rate of roots in the top $30 \mathrm{~cm}$ (Fig. 3). Differences between fertilized and unfertilized prairie showed that the pattern of root distribution was a function of nutrient availability and not a response to soil space conditions because fertilized prairie used half as much space as unfertilized prairie and still showed decreased accumulation above $30 \mathrm{~cm}$ over time (Figs. 3 and 4).

\subsection{Quantity, distribution, and quality of root biomass differs in native perennial and non-native annual ecosystems}

It is possible that maize roots had greater $\mathrm{C}$ inputs to the soil than prairie roots below a certain depth. Maize root $\mathrm{C}$ pools were much smaller than prairie root $\mathrm{C}$ pools (Fig. 2), but faster turnover times (Table 3) and lower $\mathrm{C}: \mathrm{N}$ ratios (Fig. 5) resulted in a greater proportion of the maize root $\mathrm{C}$ pool being available for stabilization in the soil compared to the prairie root $\mathrm{C}$ pool. In the top $0-30 \mathrm{~cm}$, the difference in mass between even the fertilized prairie and maize was too great to be overcome by faster turnover and greater carbon use efficiency, but the difference in root mass between the annual and perennial systems decreased with depth, while the difference in $\mathrm{C}: \mathrm{N}$ ratio increased and turnover times may have maintained the same relative relationship. Although we do not have measurements of soil $\mathrm{C}$ distribution through the soil profile prior to cultivation, data from this experiment show that the pattern of soil $\mathrm{C}$ distribution is more similar to the distribution of maize roots than the distribution of prairie roots (Fig. 1), demonstrating the importance of differing root systems in the development of the soil $\mathrm{C}$ profile.

\subsection{What do these differences in inputs tell us about the perennial prairie ecosystem under which these soils developed and the annual cropping systems under which these soils continue to change?}

The experimental location was a site of cultivation under annual crops for over 100 years following $\sim 10000$ years of perennial prairie systems. We do not have measurements of the pre-cultivation soil $\mathrm{C}$ profile, but other data from sites near our experiment (Guzman, 2009; McGranahan et al., 2014) show that the soil $\mathrm{C}$ profile shifted from a pattern of having an exponential decrease in $\mathrm{C}$ with distance from the surface to a pattern of more uniform distribution of $\mathrm{C}$ with the highest point of $\mathrm{C} 10 \mathrm{~cm}$ below the surface (Fig. 1). The loss of $\mathrm{C}$ in the soil surface after cultivation is well known and attributed to mass loss through soil erosion, increased mineralization of organic matter through tillage, and decreased belowground organic matter inputs (Davidson and Ackerman, 1993; Huggins et al., 1998). The change in soil carbon below $30 \mathrm{~cm}$ is less documented, but using a robust dataset, Veenstra et al. (2015) found soil organic $\mathrm{C}$ to increase be- 

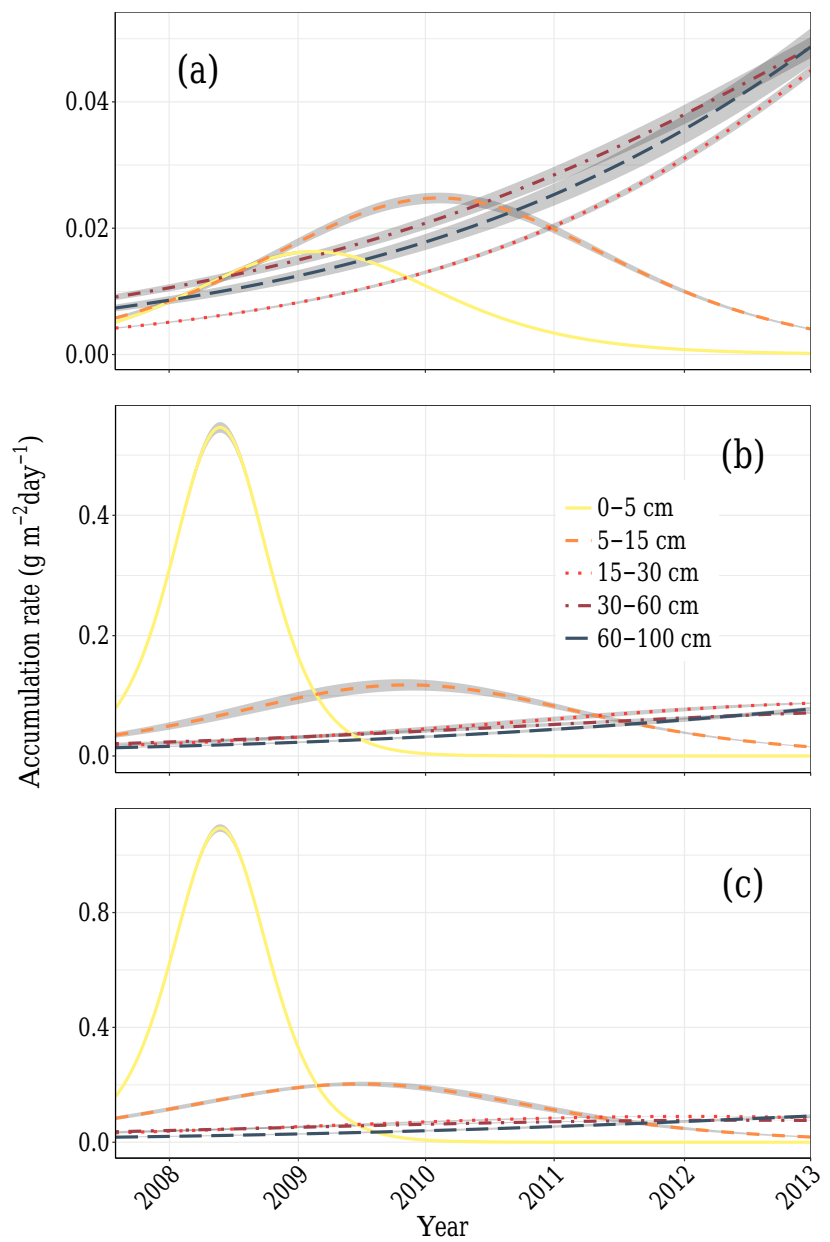

Figure 4. Modeled rates of root pool mass accumulation over 6 years in (a) continuous maize, (b) fertilized prairie, and (c) unfertilized prairie at $0-5,5-15,15-30,30-60$, and $60-100 \mathrm{~cm}$. Grey shading represents 1 standard error of the mean. Different $y$ axes are used to emphasize similarities and differences in timing and to make within-treatment relationships easier to see. Seasonal effects are smoothed.

low $35 \mathrm{~cm}$ after 50 years in maize and soybean cropping systems in Iowa, USA. Initial soil organic $\mathrm{C}$ measurements in that study were made $\sim 50$ years after these soils had already been converted to annual systems, preventing comparison to soil organic $\mathrm{C}$ levels at depth under native vegetation. The results from Veenstra et al. (2015) still show that Mollisols can and do gain soil organic $\mathrm{C}$ at deeper depths under maize and soybean systems. Similarly, David et al. (2009) and Follett et al. (2009) found cultivated sites that gained deep soil organic $\mathrm{C}$ relative to remnant prairies and grasslands.

Our relatively short-term study of 6 years did not detect significant changes in soil $\mathrm{C}$ at any depth (Fig. 1). However, differences in quantity, distribution, and $\mathrm{C}: \mathrm{N}$ ratios between the annual and perennial rooting systems we studied have important implications for how deep soil organic $\mathrm{C}$ may

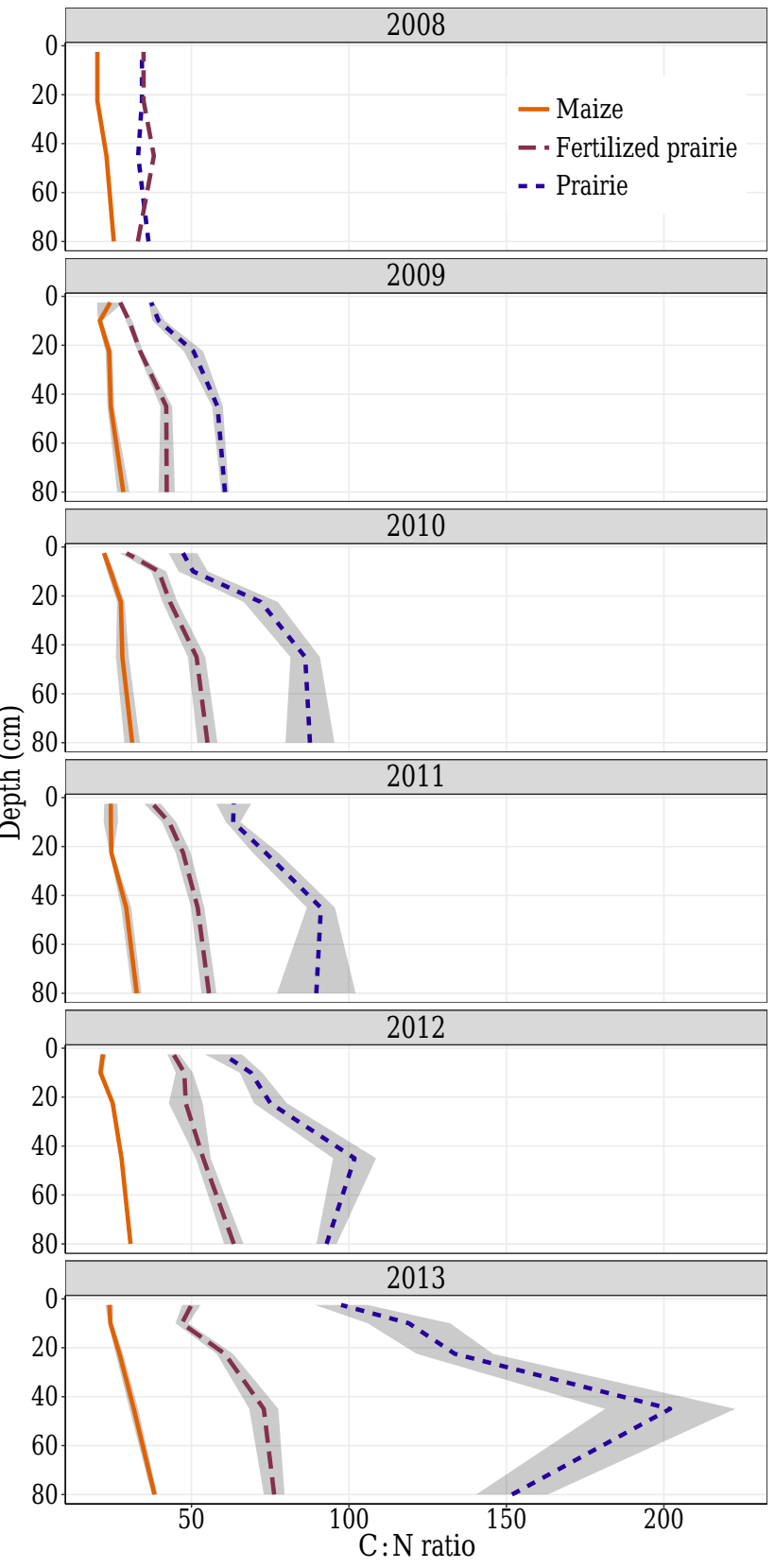

Figure 5. Root $\mathrm{C}: \mathrm{N}$ ratios with depth over time. Grey shading represents 1 standard error of the mean.

have changed and continues to change with the implementation of annual cropping systems. A large, structural-tissuedominated root $\mathrm{C}$ pool with slow turnover concentrated at shallow depths was replaced by a small, nonstructural-tissuedominated root $\mathrm{C}$ pool with fast turnover evenly distributed in the soil profile. The difference in size between these two pools has long been obvious, but it is often misleading for comparisons related to $\mathrm{C}$ accounting because differences in root turnover and tissue $\mathrm{C}: \mathrm{N}$ ratio are often not taken into consideration. As an exception, Omonode and Vyn (2006) 
discuss the possibility that slower turnover in perennial rooting systems may prevent expected increases in soil organic $\mathrm{C}$ compared to adjacent maize systems. The data presented here in the context of recent organic matter formation theory suggest that while differences in root $\mathrm{C}$ pool and soil organic $C$ relationships in maize and prairie above $20 \mathrm{~cm}$ are predominately controlled by root biomass amount, the root biomass amount is less of a factor below $20 \mathrm{~cm}$.

\section{Conclusion}

Soils are incredibly complex systems, and biogeochemical processes that determine soil $\mathrm{C}$ storage happen over a long time and in places that are difficult to study without artifactinducing disturbances. We have shown here that an increase in root $\mathrm{C}: \mathrm{N}$ ratio with depth is a potentially important and previously unconsidered factor determining the distribution of $\mathrm{C}$ in the soil profile. This factor interacts with depthdetermined differences in soil temperature, moisture, $\mathrm{O}_{2}$, soil texture, microbial communities, and existing soil $\mathrm{C}$ content and thus carries different significance in different environments. In our comparison of maize and reconstructed prairie systems, root pool $\mathrm{C}: \mathrm{N}$ ratios may be sufficiently important that they result in greater maize $\mathrm{C}$ contributions to soil organic matter than prairie $\mathrm{C}$ contributions to soil organic matter below $20 \mathrm{~cm}$. In these and many other herbaceous systems, an increase in root $\mathrm{C}: \mathrm{N}$ ratio with an increase in depth may in part explain why $50 \%$ of soil organic $\mathrm{C}$ is found below $20 \mathrm{~cm}$, while only $30 \%$ of root biomass is found in the same location. Elucidating the mechanisms determining soil $\mathrm{C}$ retention and addition is important as we strive to design systems that maintain and build soils that are productive and resilient. The role of roots and root composition, as well as the importance of soil organic $\mathrm{C}$, below $20 \mathrm{~cm}$ should be carefully considered in such designs.
Code and data availability. Data and code for this work are currently publicly stored in a GitHub repository. The DOI to find and access these files is https://doi.org/10.5281/zenodo.321910 (Dietzel, 2017). 
Appendix A: Curve fits used to generate predicted root accumulation for each depth. The mean and standard error of these curves are found in Fig. 3.

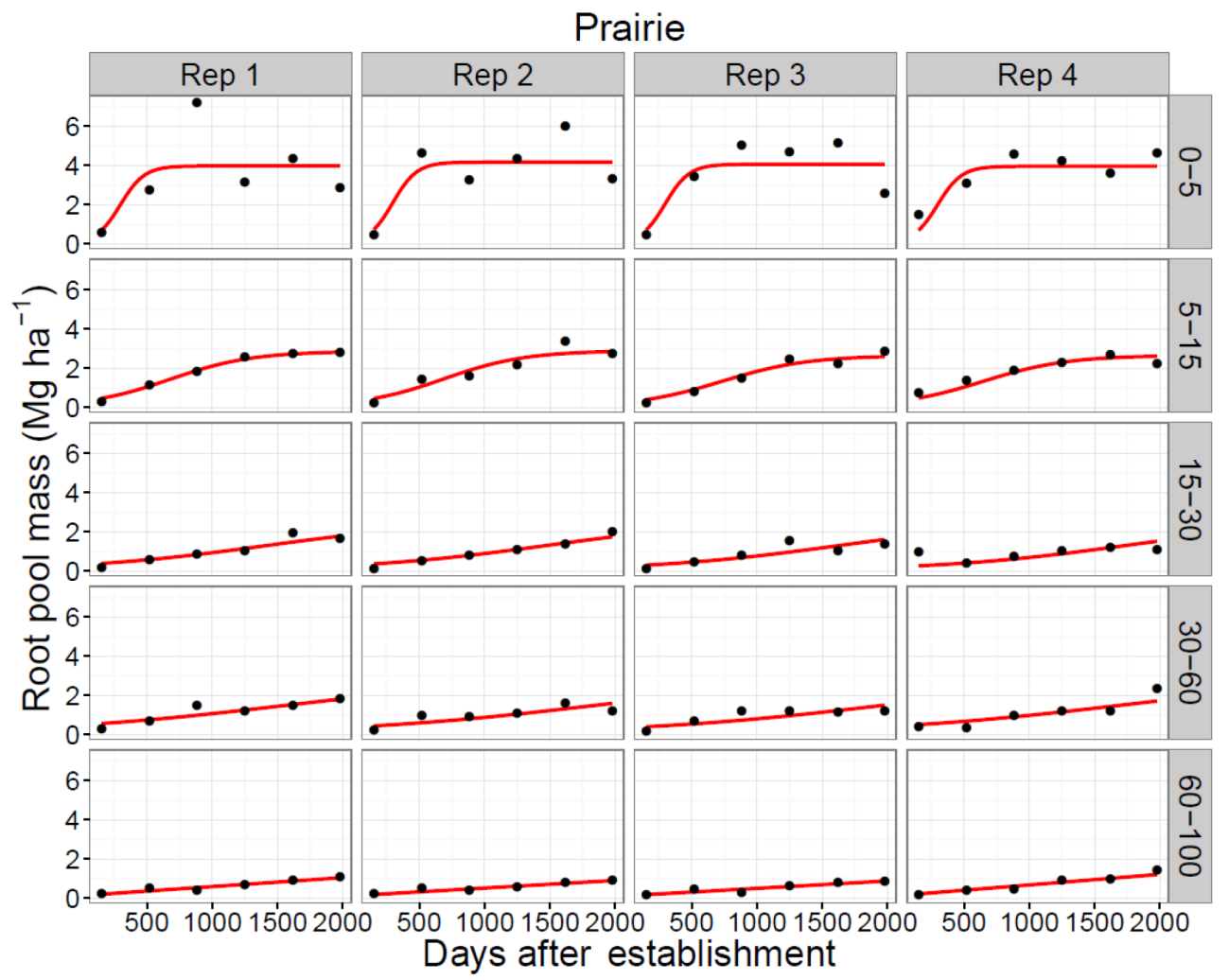

Figure A1. Logistic curves fit to root pool mass accumulation at each replication and depth increment in the prairie treatment. 
Fertilized prairie

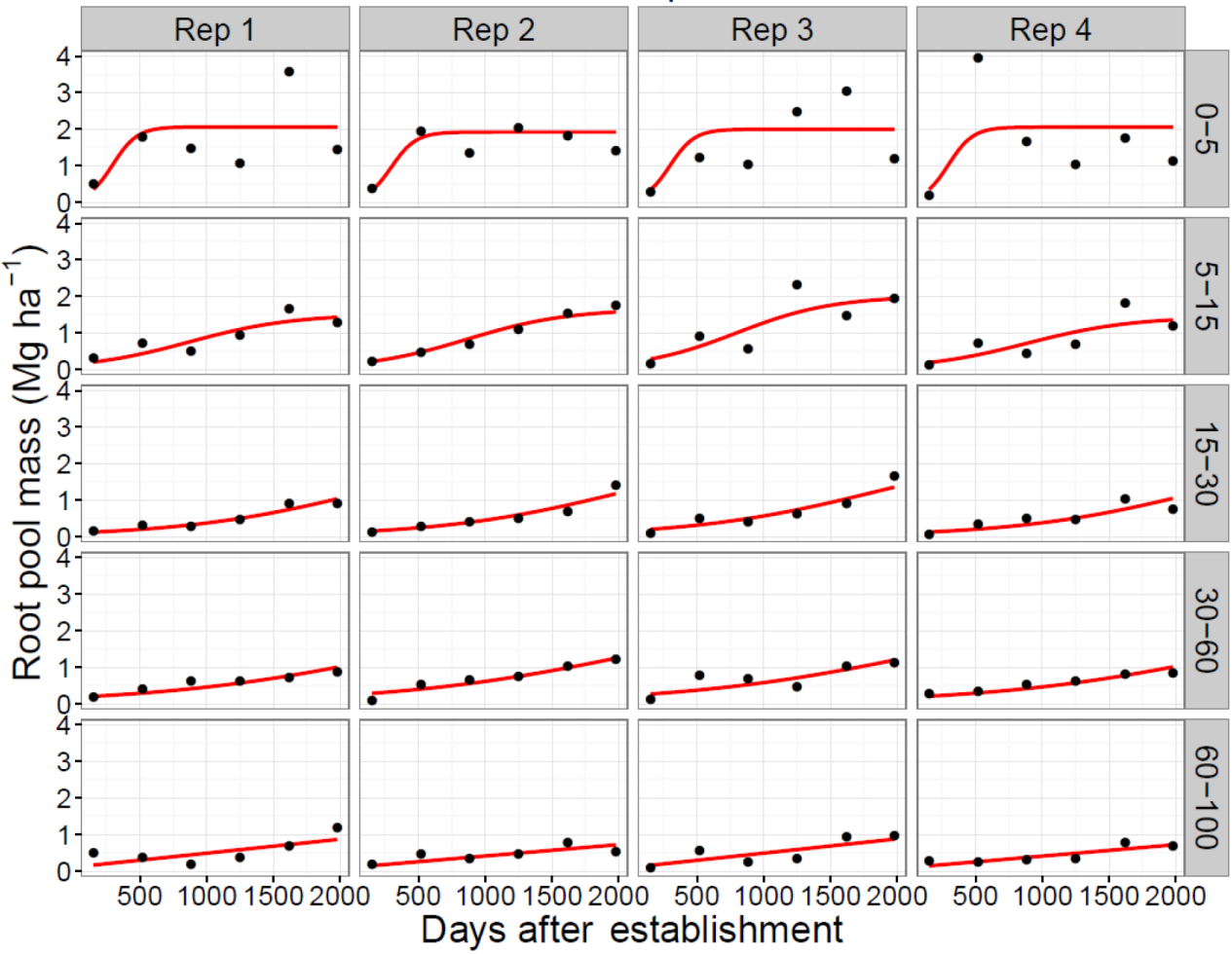

Figure A2. Logistic curves fit to root pool mass accumulation at each replication and depth increment in the fertilized prairie treatment.

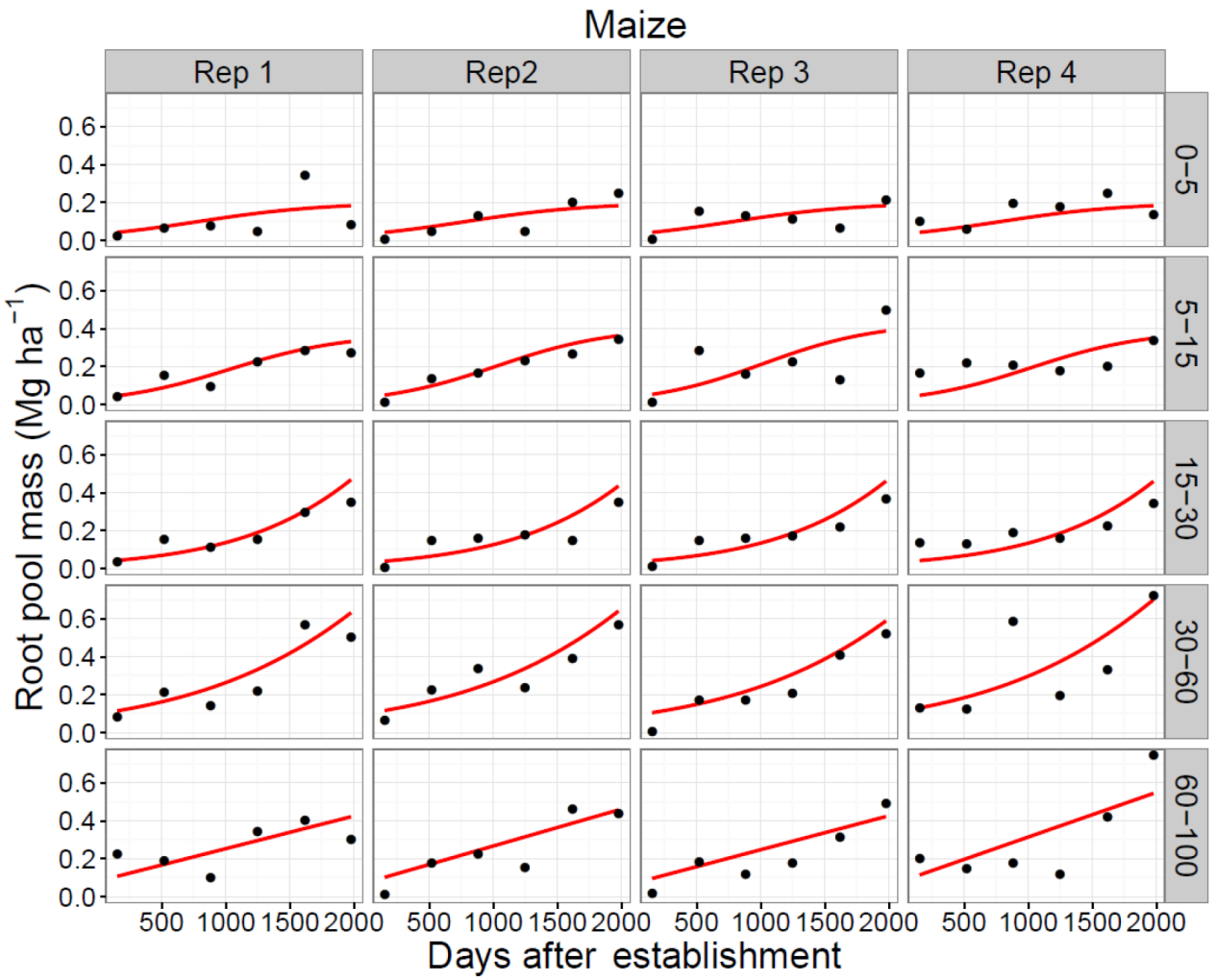

Figure A3. Logistic curves fit to root pool mass accumulation at each replication and depth increment in the maize treatment. 
Table A1. Root pool accumulation rates averaged across each growing season $\left(\mathrm{g} \mathrm{m}^{-2} \mathrm{day}^{-1}\right)$. Differences in lowercase letters indicate significant differences between depths within treatments within years (up and down). Differences in uppercase letters indicate differences between treatments within depths within years (left to right).

\begin{tabular}{|c|c|c|c|c|c|c|c|c|c|c|}
\hline \multirow[t]{2}{*}{ Year } & \multirow{2}{*}{$\begin{array}{l}\text { Depth } \\
(\mathrm{cm})\end{array}$} & \multicolumn{3}{|c|}{ Maize } & \multicolumn{3}{|c|}{ Fertilized prairie } & \multicolumn{3}{|c|}{ Unfertilized prairie } \\
\hline & & \multicolumn{9}{|c|}{$\left(\mathrm{g} \mathrm{m}^{-2} \mathrm{day}^{-1}\right)$} \\
\hline \multirow{5}{*}{2008} & $0-5$ & 0.007 & $\mathrm{a}$ & $\mathrm{C}$ & 0.205 & $\mathrm{a}$ & B & 0.411 & $\mathrm{a}$ & A \\
\hline & $5-15$ & 0.007 & $\mathrm{a}$ & $\mathrm{C}$ & 0.044 & $\mathrm{~b}$ & B & 0.102 & $\mathrm{~b}$ & A \\
\hline & $15-30$ & 0.005 & $\mathrm{a}$ & $\mathrm{C}$ & 0.019 & $\mathrm{c}$ & $\mathrm{B}$ & 0.036 & $\mathrm{c}$ & A \\
\hline & $30-60$ & 0.010 & $\mathrm{a}$ & $\mathrm{C}$ & 0.025 & $\mathrm{c}$ & B & 0.058 & $\mathrm{a}$ & A \\
\hline & $60-100$ & 0.008 & a & B & 0.015 & $\mathrm{c}$ & $\mathrm{AB}$ & 0.019 & $\mathrm{a}$ & A \\
\hline \multirow{5}{*}{2009} & $0-5$ & 0.015 & $\mathrm{a}$ & $\mathrm{C}$ & 0.315 & $\mathrm{a}$ & B & 0.632 & $\mathrm{a}$ & A \\
\hline & $5-15$ & 0.016 & $\mathrm{a}$ & $\mathrm{C}$ & 0.087 & $\mathrm{~b}$ & $\mathrm{~B}$ & 0.177 & $\mathrm{~b}$ & A \\
\hline & $15-30$ & 0.007 & $\mathrm{a}$ & $\mathrm{C}$ & 0.029 & $\mathrm{c}$ & $\mathrm{B}$ & 0.051 & $\mathrm{c}$ & A \\
\hline & $30-60$ & 0.015 & $\mathrm{a}$ & $\mathrm{C}$ & 0.036 & $\mathrm{c}$ & B & 0.084 & $\mathrm{~d}$ & A \\
\hline & $60-100$ & 0.012 & $\mathrm{a}$ & B & 0.021 & $\mathrm{c}$ & $\mathrm{AB}$ & 0.027 & $\mathrm{e}$ & A \\
\hline \multirow{5}{*}{2010} & $0-5$ & 0.013 & $\mathrm{a}$ & A & 0.011 & $\mathrm{~d}$ & $\mathrm{AB}$ & 0.021 & $\mathrm{~d}$ & A \\
\hline & $5-15$ & 0.024 & $\mathrm{a}$ & $\mathrm{D}$ & 0.117 & $\mathrm{a}$ & B & 0.197 & $\mathrm{a}$ & A \\
\hline & $15-30$ & 0.012 & $\mathrm{a}$ & $\mathrm{C}$ & 0.042 & $\mathrm{bc}$ & B & 0.067 & $\mathrm{c}$ & A \\
\hline & $30-60$ & 0.020 & $\mathrm{a}$ & $\mathrm{C}$ & 0.047 & $\mathrm{~b}$ & B & 0.090 & $\mathrm{~b}$ & A \\
\hline & $60-100$ & 0.016 & $\mathrm{a}$ & $\mathrm{BC}$ & 0.030 & $\mathrm{c}$ & $\mathrm{AB}$ & 0.037 & $\mathrm{~d}$ & A \\
\hline \multirow{5}{*}{2011} & $0-5$ & 0.005 & $\mathrm{a}$ & A & 0.000 & $\mathrm{c}$ & $\mathrm{AB}$ & 0.000 & $\mathrm{e}$ & A \\
\hline & $5-15$ & 0.022 & $\mathrm{a}$ & $\mathrm{D}$ & 0.093 & $\mathrm{a}$ & B & 0.131 & $\mathrm{a}$ & A \\
\hline & $15-30$ & 0.018 & $\mathrm{a}$ & $\mathrm{C}$ & 0.058 & $\mathrm{~b}$ & B & 0.082 & $\mathrm{~b}$ & A \\
\hline & $30-60$ & 0.027 & $\mathrm{a}$ & $\mathrm{C}$ & 0.056 & $\mathrm{~b}$ & B & 0.068 & $\mathrm{c}$ & A \\
\hline & 60-100 & 0.023 & $\mathrm{a}$ & $\mathrm{C}$ & 0.041 & $\mathrm{~b}$ & $\mathrm{AB}$ & 0.051 & $d$ & A \\
\hline \multirow{5}{*}{2012} & $0-5$ & 0.001 & $\mathrm{c}$ & A & 0.000 & $\mathrm{c}$ & A & 0.000 & $\mathrm{~d}$ & A \\
\hline & $5-15$ & 0.012 & b & $\mathrm{D}$ & 0.048 & $\mathrm{~b}$ & B & 0.061 & $\mathrm{~b}$ & A \\
\hline & $15-30$ & 0.028 & $\mathrm{a}$ & $\mathrm{D}$ & 0.074 & a & B & 0.089 & $\mathrm{a}$ & A \\
\hline & $30-60$ & 0.034 & $\mathrm{a}$ & B & 0.058 & $\mathrm{~b}$ & A & 0.041 & $\mathrm{c}$ & B \\
\hline & $60-100$ & 0.033 & a & $\mathrm{D}$ & 0.056 & $\mathrm{~b}$ & B & 0.068 & $\mathrm{~b}$ & A \\
\hline \multirow{5}{*}{2013} & $0-5$ & 0.000 & $\mathrm{~b}$ & A & 0.000 & $\mathrm{e}$ & A & 0.000 & $\mathrm{c}$ & A \\
\hline & $5-15$ & 0.005 & $\mathrm{~b}$ & $\mathrm{~B}$ & 0.019 & d & A & 0.023 & $\mathrm{~b}$ & A \\
\hline & $15-30$ & 0.041 & $\mathrm{a}$ & $\mathrm{D}$ & 0.086 & $\mathrm{a}$ & A & 0.087 & $\mathrm{a}$ & A \\
\hline & $30-60$ & 0.041 & $\mathrm{a}$ & B & 0.052 & $\mathrm{c}$ & A & 0.022 & $\mathrm{~b}$ & $\mathrm{C}$ \\
\hline & $60-100$ & 0.045 & $\mathrm{a}$ & $\mathrm{C}$ & 0.074 & $\mathrm{~b}$ & B & 0.087 & $\mathrm{a}$ & A \\
\hline
\end{tabular}


Competing interests. The authors declare that they have no conflict of interest.

Acknowledgements. This project was supported by the following: the Agriculture and Food Research Initiative competitive grant numbers 2012-67011-1966 and 2016-67012-25170 from the USDA National Institute of Food and Agriculture; Iowa State University's College of Agriculture and Life Sciences, Department of Agronomy, Graduate Program in Sustainable Agriculture; and the Wallace Chair for Sustainable Agriculture. We thank Dave Sundberg, Bruce Hall, Kevin Day, Jake Anderson, Brent Beelner, Shane Bugeja, Robin Gómez-Gómez, Céline Guignard, Sarah Hirsh, Brady North, Nick Siepker, and Madeline Tomka for technical assistance in the field and laboratory. We are also grateful to Lendie Follett and the R community for help with statistics and coding as well as Mike Castellano and several anonymous reviewers for useful comments on earlier drafts of the paper.

Edited by: Marie-France Dignac

Reviewed by: two anonymous referees

\section{References}

Badri, D. V. and Vivanco, J. M.: Regulation and function of root exudates, Plant Cell Environ., 32, 666-681, 2009.

Balesdent, J. and Balabane, M.: Major contribution of roots to soil carbon storage inferred from maize cultivated soils, Soil Biol. Biochem., 28, 1261-1263, 1996.

Beniston, J. W., DuPont, S. T., Glover, J. D., Lal, R., and Dungait, J. A.: Soil organic carbon dynamics 75 years after land-use change in perennial grassland and annual wheat agricultural systems, Biogeochemistry, 120, 37-49, 2014.

Blackmer, A., Voss, R.D., and Mallarino, A.P.: Nitrogen fertilizer recommendations for corn in Iowa, Iowa State University Extension, Ames, Iowa, 1997.

Buyanovsky, G., Kucera, C., and Wagner, G.: Comparative analyses of carbon dynamics in native and cultivated ecosystems, Ecology, 68, 2023-2031, 1987.

Castellano, M. J., Mueller, K. E., Olk, D. C., Sawyer, J. E., and Six, J.: Integrating plant litter quality, soil organic matter stabilization, and the carbon saturation concept, Glob. Change Biol., 21, 3200-3209, 2015.

Cotrufo, M. F., Soong, J. L., Horton, A. J., Campbell, E. E., Haddix, M. L., Wall, D. H., and Parton, W. J.: Formation of soil organic matter via biochemical and physical pathways of litter mass loss, Nat. Geosci., 8, 776-781, 2015.

David, M. B., McIsaac, G. F., Darmody, R. G., and Omonode, R. A.: Long-term changes in mollisol organic carbon and nitrogen, J. Environ. Qual., 38, 200-211, 2009.

Davidson, E. A. and Ackerman, I. L.: Changes in soil carbon inventories following cultivation of previously untilled soils, Biogeochemistry, 20, 161-193, 1993.

Dietzel, R.: Ranae/Roots-to-SoilC: A deeper look, Zenodo, https://doi.org/10.5281/zenodo.321910, 2017.

Dietzel, R., Jarchow, M. E., and Liebman, M.: Above- and Belowground Growth, Biomass, and Nitrogen Use in Maize and Re- constructed Prairie Cropping Systems, Crop Sci., 55, 910-923, https://doi.org/10.2135/cropsci2014.08.0572, 2015.

Dietzel, R., Jarchow, M. E., and Liebman, M.: Above- and Belowground Growth, Biomass, and Nitrogen Use in Maize and Reconstructed Prairie Cropping Systems, Crop Sci., 55, 910-923, https://doi.org/10.2135/cropsci2014.08.0572, 2015.

DuPont, S. T., Beniston, J., Glover, J., Hodson, A., Culman, S., Lal, R., and Ferris, H.: Root traits and soil properties in harvested perennial grassland, annual wheat, and never-tilled annual wheat, Plant Soil, 381, 405-420, 2014.

Follett, R. F., Kimble, J. M., Pruessner, E. G., Samson-Liebig, S., and Waltman, S.: Soil Organic Carbon Stocks with Depth and Land Use at Various U.S. Sites, in: Soil Carbon Sequestration and the Greenhouse Effect, 2nd Edn., ASA-CSSA-SSS, Madison, SSSA Special Publication 57, 29-46, 2009.

Fontaine, S., Barot, S., Barre, P., Bdioui, N., Mary, B., and Rumpel, C.: Stability of organic carbon in deep soil layers controlled by fresh carbon supply, Nature, 450, 277-281, 2007.

Gill, R., Burke, I. C., Milchunas, D. G., and Lauenroth, W. K.: Relationship between root biomass and soil organic matter pools in the shortgrass steppe of eastern Colorado, Ecosystems, 2, 226236, 1999.

Gill, R. A. and Burke, I. C.: Influence of soil depth on the decomposition of bouteloua gracilis roots in the shortgrass steppe, Plant Soil, 241, 233-242, 2002.

Gregory, A., Dungait, J., Watts, C., Bol, R., Dixon, E., White, R., and Whitmore, A.: Long-term management changes topsoil and subsoil organic carbon and nitrogen dynamics in a temperate agricultural system, Eur. J. Soil Sci., 67, 421-430, 2016.

Guo, L. B. and Gifford, R.: Soil carbon stocks and land use change: A meta analysis, Glob. Change Biol., 8, 345-360, 2002.

Guzman, J. G. and Al-Kaisi, M. M.: Soil carbon dynamics and carbon budget of newly reconstructed tall-grass prairies in South Central Iowa, J. Environ. Qual., 39, 136-146, https://doi.org/10.2134/jeq2009.0063, 2009.

Heggenstaller, A. H., Moore, K. J., Liebman, M., and Anex, R. P.: Nitrogen influences biomass and nutrient partitioning by perennial, warm-season grasses, Agron. J., 101, 1363-1371, 2009.

Huggins, D., Buyanovsky, G., Wagner, G., Brown, J., Darmody, R., Peck, T., Lesoing, G., Vanotti, M., and Bundy, L.: Soil organic C in the tallgrass prairie-derived region of the corn belt: Effects of long-term crop management, Soil Till. Res., 47, 219-234, 1998.

Jarchow, M. E. and Liebman, M.: Nitrogen fertilization increases diversity and productivity of prairie communities used for bioenergy, GCB Bioenergy, 5, 281-289, 2013.

Jobbágy, E. G. and Jackson, R. B.: The vertical distribution of soil organic carbon and its relation to climate and vegetation, Ecol. Appl., 10, 423-436, 2000.

Kong, A. Y. and Six, J.: Tracing root vs. residue carbon into soils from conventional and alternative cropping systems, Soil Sci. Soc. Am. J., 74, 1201-1210, 2010.

Liang, C. and Balser, T. C.: Preferential sequestration of microbial carbon in subsoils of a glacial-landscape toposequence, Dane county, WI, USA, Geoderma, 148, 113-119, 2008.

McGranahan, D. A., Daigh, A. L., Veenstra, J. J., Engle, D. M., Miller, J. R., and Debinski, D. M.: Connecting soil organic carbon and root biomass with land-use and vegetation in temperate grassland, The Scientific World Journal, 2014, 487563, https://doi.org/10.1155/2014/487563, 2014. 
Omonode, R. A. and Vyn, T. J.: Vertical distribution of soil organic carbon and nitrogen under warm-season native grasses relative to croplands in west-central Indiana, USA, Agr. Ecosyst. Environ., 117, 159-170, 2006.

O’Brien, S. L., Jastrow, J. D., Grimley, D. A., and Gonzalez-Meler, M. A.: Moisture and vegetation controls on decadal-scale accrual of soil organic carbon and total nitrogen in restored grasslands, Glob. Change Biol., 16, 2573-2588, 2010.

Pinheiro, J. and Bates, D.: Mixed-Effects Models in S and S-PLUS, Springer-Verlag New York, https://doi.org/10.1007/b98882, 2000.

Pinheiro, J., Bates, D., DebRoy, S., Sarkar, D., and Team, R. C.: nlme: Linear and nonlinear mixed effects models, R package version 3.1-113, available at: https://CRAN.R-project.org/package= nlme (last access: 15 July 2014), 2013.

Rasse, D. P., Rumpel, C., and Dignac, M.-F.: Is soil carbon mostly root carbon? Mechanisms for a specific stabilisation, Plant Soil, 269, 341-356, 2005.

Rumpel, C. and Kögel-Knabner, I.: Deep soil organic matter - a key but poorly understood component of terrestrial Ccycle, Plant Soil, 338, 143-158, 2011.
Silver, W. L. and Miya, R. K.: Global patterns in root decomposition: Comparisons of climate and litter quality effects, Oecologia, 129, 407-419, 2001.

Six, J., Conant, R., Paul, E. A., and Paustian, K.: Stabilization mechanisms of soil organic matter: Implications for C-saturation of soils, Plant Soil, 241, 155-176, 2002.

Tufekcioglu, A., Raich, J., Isenhart, T., and Schultz, R.: Biomass, carbon and nitrogen dynamics of multi-species riparian buffers within an agricultural watershed in Iowa, USA, Agroforest. Syst., 57, 187-198, 2003.

van Es, H., Gomes, C., Sellmann, M., and van Es, C.: Spatiallybalanced complete block designs for field experiments, Geoderma, 140, 346-352, 2007.

Veenstra, J. J. and Lee Burras, C.: Soil Profile Transformation after 50 Years of Agricultural Land Use, Soil Sci. Soc. Am. J., 79, 1154-1162, https://doi.org/10.2136/sssaj2015.01.0027, 2015.

Weaver, J. E., Hougen, V. H., and Weldon, M. D.: Relation of root distribution to organic matter in prairie soil, Bot. Gaz., 96, 389420, 1935.

Wiles, L. J., Barlin, D. H., Schweizer, E. E., Duke, H. R., and Whitt, D. E.: A new soil sampler and elutriator for collecting and extracting weed seeds from soil, Weed Technol., 10, 35-41, 1996. 